Cilt / Volume: 2

Say l / Is s u e : 1

Yaz / Sum mer 2021

S e l çu $\mathrm{k}$ Ü n iver si t e si

İslami İlimler Fakültesi Dergisi

\title{
Ricâl Tenkit Araştırmalarının Dijital Kaynakları: İnternet Siteleri
}

Araştırma

Research

\section{İsmail Kurt}

Dr. Öğr. Üyesi, Artvin Çoruh Üniversitesi, İlahiyat Fakültesi, Hadis Anabilim Dalı Assistant Professor, Artvin Coruh University, Faculty of Theology, Department of Hadith, Artvin, Turkey

ismailkurt@artvin.edu.tr (iD) https://orcid.org/0000-0002-9873-9369

Kurt, İsmail. "Ricâl Tenkit Araștırmalarının Dijital Kaynakları: İnternet Siteleri". Tevilat 2/1 (2021), 89-105.

doi https://doi.org/10.53352/tevilat.1003440

Günümüz ilim sahasında kaynakların dijitalleșme süreci hızla devam etmektedir. Aktüalitesini her daim koruyan ricâl tenkit ilmi de bu gelişmelere kișisel ya da kurumsal girişimlerle ayak uydurmaya çalışmaktadır. $\mathrm{Bu}$ vesileyle ricâl edebiyatına dair kaynaklarda yer alan değerlendirmeler çevrimiçi ya da çevrimdıșı olarak kullanıcılara açılmaktadır. Ricâl tenkit verilerini içeren internet siteleri online olup internet bağlantısının olduğu her yerde erişilebilmekte, böylelikle araştırmacılara büyük kolaylıklar sağlamaktadır. Bununla birlikte sitelerin sayısal fazlalığı onların değerlendirilmesini ve nitelikli olanların belirlenmesini gerekli kılmaktadır. Bu amaçla makalemizde ricâl tenkit verilerini ihtiva etmekle öne çıkmış bazı siteler konu edilmiştir. Söz konusu sitelere ilaveten el-Mektebetü'ş-şâmile adlı program da araştırmaya dâhil edilmiştir. Araştırmaya konu olan siteler; alan adı, kapsayıcılık, kullanım kolaylığı gibi açılardan incelenmiștir. Böylelikle internet siteleri üzerinden araştırma yapacak günümüz araştırmacılarına yön verecek değerlendirmeler yapma imkânına ulaşılmıştır. Bunun yanında ülkemizde özellikle ricâl tenkit temalı bir sitenin kurulma ihtiyacına da işaret edilerek tavsiyelerde bulunulmuştur. $\mathrm{Bu}$ tavsiyelerin temelinde sade, kullanıcı dostu ve kaynak gösterimi gibi özelliklerin olmasına vurgu yapılmıştır.

Anahtar Kelimeler: Hadis, Râvî, Ricâl Tenkiti, Dijital Kaynak, İnternet Siteleri. 


\section{Digital Resources for Transmitter Criticism Research: Websites}

In today's scientific field, the digitalization process of resources continues rapidly. The discipline of transmitter criticism, which always preserves its actuality, tries to keep pace with the digitalization via personal or institutional attempts. Therefore, the evaluations in the sources regarding the literatüre of aldjarh wa'l-ta'dill are opened to users online or offline. The websites containing the data on the transmitter criticism are online and accessible from everywhere, which enables researchers to learn what they want about transmitters. However, the large quantity of those websites makes it necessary to evaluate them and to determine the qualified ones. For this purpose, in our article, certain websites that have come to the forefront with their content of criticism are discussed. In addition to the websites, the program called al-Maktaba asShamela is also included in the research. The sites subject to the review were examined in terms of domain name, inclusivity and ease of use. Thus, evaluations were made to guide today's researchers who will conduct research on websites. Additionally, some recommendations were made by pointing out the neet of establishing a site with the theme of criticism, especially in our country. The main features, recommended, on a possible website of the discipline of transmitter criticism are simplicity, user-friendliness and reference display.

Keywords: Hadith, Transmitter, Transmitter Criticism, Digital Resource, Abstract $\mid$ Websites.

\section{Giriş}

Bilgisayar teknolojisinin hayatımıza girerek herkes tarafından kolayca ulaşılabilir bir cihaz olması ve buna ilaveten kişiler/bilgisayarlar arası hızlı iletişimin yaygınlık kazanması birçok sahada yeni imkânların doğmasına sebep olmuştur. Temelinde bilgi alışverişi olan bu imkânların temayüz ettiği alanlardan birisi de bilimsel araştırma sahasıdır. Bu sahalardan biri de hadis ilmine dair veri ihtiva eden internet siteleridir.

Esasında ülkemizde hadis ilmi ile ilgili veri ihtiva eden siteler hakkında yer yer değerlendirmeler yapılmıștır. Bunlar arasında Ínternette Rıhle ile İçerik, Sunum ve Nitelikleri Bakımından Türkçe Internet Sayfalarında Hadis ${ }^{1}$ adlı makaleler, başlıkları ve içerikleri ile ön plana çıkmaktadır. Ancak döneminde önemli bilgiler sunan bu makalelerde genel bir tanıtım yapılmış ve bu makaleler, her an "güncellenen dijital dünyanın" takibi için aktüalitesini kaybetmiştir.

Makalemizin hazırlanmasında temel üç saik bulunmaktadır. Bunlardan ilki, hadis ilmi ile alakalı internet siteleri hakkında tekrardan bir değerlendirme yapılma ihtiyacıdır. Makalemizin konusunun ricâl tenkit verisi içeren sayfalarla

\footnotetext{
1 Hayati Yılmaz, "İnternette Rıhle”, Hadis Tetkikleri Dergisi 2/1 (2004); Hayati Yılmaz, "İçerik, Sunum ve Nitelikleri Bakımından Türkçe İnternet Sayfalarında Hadis”, Sakarya Üniversitesi Illahiyat Fakültesi Dergisi 16 (2007), 63-76.
} 
sınırlandırılması ise bazı araștırmacıların incelenen sitelere dair rağbetlerinin görülmesi ve onlara bu konuda yol gösterecek nitelikte bir yazı kaleme alma ihtiyacının hâsıl olmasıdır. Son olarak da ülkemizde sadece ricâl tenkit verisi içeren internet sitesi formatında bir dijital kaynağın oluşturulma ihtiyacına ve muhtemel site haritasına dikkat çekmektedir.

İnternet sayfaları arasında ricâl tenkit verisini içeren Şiî kaynaklar dâhil birçok site bulunmaktadır. ${ }^{2}$ Ancak bir makale boyutunu aşacak derecede bulunan bu sayının sınırlandırılması elzemdir. Bu sebeple çalışmamızın kapsamını http://hadithtransmitters.hawramani.com, https://sunnah.alifta.gov.sa, https://hadith.islam-db.com/all-narrators ve https://islamic-content.com/rawis/ isimli siteler oluşturacaktır.

Makalemizde incelemeye konu olan siteler; domain adı, ricâl tenkit bilgisini barındırma oranı, sitelerin kullanımı ve iki râvî özelinde araştırma pratiğinden oluşmaktadır. Özellikle son kısımda el-Mektebetü'ş-şâmile programı da incelemeye dâhil edilerek internet siteleri hakkında değerlendirme yapılacaktır. Böylelikle ricâl tenkidine dair çalışmalarda bulunmak isteyen araștırmacılara hem yol gösterilmiş hem de ülkemizde râvîlerle alakalı bir sitenin oluşturulma imkanına dikkat çekilmiş olunacaktır.

\section{Ricâl Tenkit Muhtevasına Sahip Siteler}

İnternet hizmeti kullanılarak yapılacak ricâl çalışmasında bu konuya dair verileri içeren sitelere ya rastlantısal ya da doğrudan site adını yazarak ulaşmak mümkündür. Rastlantısal bulguya râvî isminin yazılması veya ricâle dair anahtar kelimelerin girilmesi sonucu yapılan sorgu ile ulaşılabilir. Doğrudan site ismi yazılarak yapılacak araştırmada ise site adının bilinirliliği esastır. Bu çalışmada site isimlerinin zikredilmesi, söz konusu sitelerin erbabı yanında bilinirliğini artıracağı muhakkaktır. Bununla birlikte bazı anahtar kelimelerin Google arama motoruna yazılarak söz konusu sitelere ulaşılıp ulaşılmadığına dair bir denemeyi burada paylaşmak istiyoruz. Bunun için رجال lafızları ve birkaç râvî ismi kullanılacaktır.

رجال الحديث lafzı ile yapılan sorgulama, ilk sonuç sayfasında burada inceleyeceğimiz hiçbir siteye yer vermemektedir. ${ }^{3}$ رواة الحديث sorgusunda ise "Hadith Transmitters ve Hadith.islam-db" alan adlı iki site, ilk sonuç ekranında çlkmaktadır. ${ }^{4}$ sorgusunda ise ricâl ile ilgili sitelerden daha fazla hadis usulüyle alakalı sonuçları listelemektedir. ${ }^{5}$ Şu durumda zikredilen kilit kavramların basit bir sorgusunda istenilen sonuçları vermediği söylenebilir.

2 http://qadatona.org, https://areq.net, https://islamweb.net gibi siteler rical bilgisi içeren sitelere örnek olarak gösterilebilir.

3 https://www.google.com/search?client=opera\&q=رجال+الحديثsourceid=opera\&ie=UTF8\&oe=UTF-8 (28.09.2021)

4 https://www.google.com/search?client=opera\&q=روواة+الحديث\&sourceid=opera\&ie=UTF8\&oe=UTF-8 (28.09.2021)

5 https://www.google.com/search?client=opera\&q=الجرح+و التعديل\&sourceid=opera\&ie=UTF8\&oe=UTF-8 (28.09.2021) 
Doğrudan râvî ismi ile yapılan sorgu neticesinde sonuçların gösterildiği ilk sayfada "Hadith Transmitters ve Hadith.islam-db" adlı sitelerin listelendiği görülmektedir. ${ }^{6}$ Şu durumda söz konusu sitelerin araştırmacı için sıklıkla karşılaşılan ve çabuk ulaşılabilen bir kaynak olduğu ifade edilmelidir.

\section{Domain İsmi Açısından Sitelerin Değerlendirilmesi}

Makalemizde incelemeye konu olan sitelerin domain yani alan adı açısından değerlendirilmesi hem söz konusu sitelerin kimliğini ortaya koymada hem de bu konuda alternatif üretilmesinde önemli sonuçlar ortaya koyabilecek hususlardır. Çünkü hangi dilde olursa olsun araştırmacı öncelikle araştırma alanı ile ilgili karakteristik kavramlar üzerinden hareket etmeye yatkındır.

$\mathrm{Bu}$ bağlamda İngilizce olan ve hadis aktaran (râvî) anlamına gelen Hadith Transmitter ismi oldukça başarılı bir seçimdir. Google üzerinden gerçekleştirilen basit bir hadithtransmitter sorgusu 8.610.000 sonuç vermekte olup ilk bulgu Hadithtransmitter.hawramani sitesine aittir. ${ }^{7}$ İncelemeye konu olan diğer siteler ise domain adlarında doğrudan râvîlere işaret eden herhangi bir lafız kullanmamakta, râvîlerle alakalı verileri ise sitenin ana sayfasındaki bölümde zikredilen " الرواة، الشخصيات، رواة" menü ya da menü altında açllır listede (Pop-up menu) yer vermektedir. Bu durum, söz konusu sitelerin hadis râvîlerini de kapsayacak şekilde geniş bir malumatı barındırmayı amaçlamasından kaynaklanmaktadır. Ancak hadisi oluşturan iki unsurdan biri olan senette yer alan râvîlerin müstakil bir şekilde dijital ortama aktarılarak araștırmacı ve meraklılarına sunulması, bu yapılırken de doğrudan râvîleri çağrıştıracak bir domain adının kullanılması konunun ehemmiyeti açısından önemli bir husustur. Bunun için "hadis râvîleri” ifadesi ülkemiz kullanıcıları için ideal bir alan adı olabilir.

\section{Kullanım Açısından Sitelerin Tanıtımı}

2000'li yılların başlarında bilgisayar ya da internet imkânının varlığı başlı başına bir ayrıcalıktı. Fakat günümüze geldiğimizde söz konusu hususlar gündelik hayatın bir parçası oldu. Dolayısıyla bir internet sitesi rağbet görecekse kullanıcı dostu ara yüze ve pratik bir kullanıma sahip olmalıdır. $\mathrm{Bu}$ durumdan ricâl tenkidi ile ilgili veriler barındıran siteler de muaf değildir. Dolayısıyla makalemize konu olan sitelerin kullanım açısından da tenkidi elzemdir.

6 https://www.google.com/search?client=opera\&q=عsourceid =opera\&ie=UTF-8\&oe=UTF-8, https://www.google.com/search?client=opera \& q=ع عمان+بن+أبي+شيية+العبسية/ sourceid=opera\&ie=UTF-8\&oe=UTF-8 (28.09.2021) https://www.google.com/search?q=hadith+transmitter\&client=opera\&hs=ime\&ei= TBJSYf330-X7_UPgfy0qAs\&start=0\&sa=N\&ved=2ahUKEwj9zfz96J_zAhVl_7sIHQEDbU4FBDy0wN6BAgBEDw\&biw=1222\&bih=587\&dpr=1.31 (28.09.2021) 


\subsection{Hadith Transmitters}

Ikram Hawramani tarafından yönetilen "The Hadith Transmitters Encyclopedia" projesinin internet sitesi olan bu sayfa dünyanın en kapsamlı râvî biyografi sözlügünü oluşturmayı amaçladığını iddia etmektedir. Yine buradaki ifadeye göre sitede 65 ricâl kitabı ve 135068 veri girişi bulunmaktadır. Söz konusu kitapların el-Mektebetü'ş-şâmile programından alındığı ve XX. Asırdan önce yazılan kitaplar olduğu ifade edilmektedir. ${ }^{8}$ Bununla birlikte yer yer daha güncel eserlerin de varlığı görülmektedir. ${ }^{9}$ Shamela sitesinin temel kaynak olarak kabul edilmesi, sitenin ricâl edebiyatına dair dünyanın en kapsamlı dijital mecra olma hedefinin ulaşılabilir bir hedef olmaktan uzak olduğunu göstermektedir. Buna ilaveten sitedeki araştırma imkânının el-Mektebetü'ş-şâmile sitesinden daha pratik olduğunu ifade edebiliriz. ${ }^{10}$ Tecrübelerimiz, ricâle dair yapılacak araştırmalarda adı geçen sitenin başka siteler karşısında daha fazla imkân sunmaktan uzak olduğunu göstermektedir. Bunun başlıca sebebinin ise bilgiyi tasnif etmeden yani doğrudan kitapta yazılı olanı sunmaktan kaynaklandığı söylenebilir. Bu durum

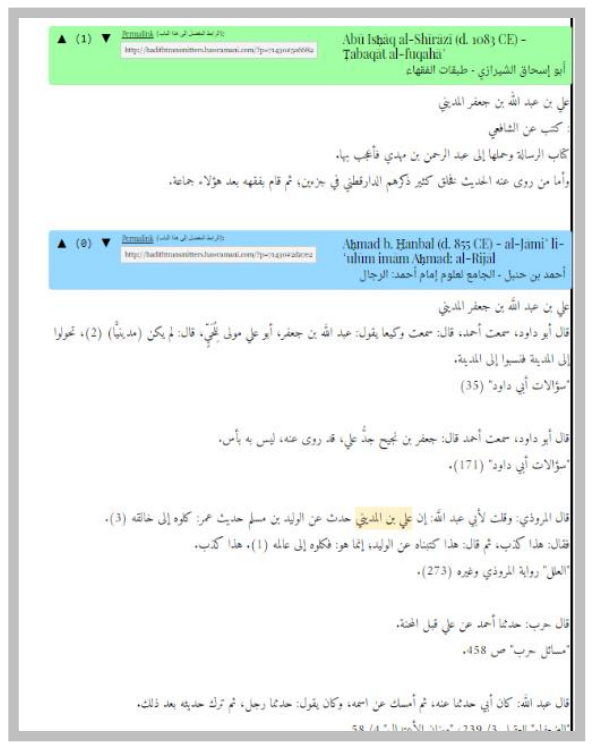

Ekran Görüntüsü 1: The Hadith

Transmitters Encyclopedia sitesine ait ekran görüntüsü Ali b. el-Medînî (ö. 234/848-49) ${ }^{11}$ sorgusunu gösteren aşağıdaki ekran görüntüsünden de hızlıca anlaşılabilir.

Ekran görüntüsüne dikkat edilirse site Ali b. el-Medînî ismini yukarıda işaret edilen kaynaklardan aramış ve doğrudan bulunan verileri ilgili kitabın sayfası olarak sunmuștur. $\mathrm{Bu}$ yöntemin öne çıkan pratik sonucu bilgiye kaynaklı eden kitabı göstermekten öteye geçmemektedir. Bunu yaparken sayfa ve cilt numarası vermemesi ise sitenin işlevselliğini daha da azaltmaktadır.

\subsection{Sunnah al-Ifta}

Kurumsal bir desteğe sahip olduğu anlaşılan bu sitenin kimliğinde Fetva ve İlmî Araştırmalar Başkanlığı/Suudi Arabistan ifadesi yer almaktadır. Site hadis ilmi ile ilgili alt başlıklar da içermekle birlikte râvîlere dair alt sayfa ön plana çlkmaktadır. ${ }^{12}$ Site üzerinden örnek bir araştırmanın ekran görüntüsü șu şekildedir:

8 http://hadithtransmitters.hawramani.com

91966 doğumlu Hâtim b. Ârif el-Avnî’nin Zeylu lisâni'l-mizân adlı eseri bu duruma örnek olarak gösterilebilir. (http://hadithtransmitters.hawramani.com/hatim-b-arif-al-awni-dhayl-lisan-almizan/ 30.09.2021)

10 https://al-maktaba.org/search

11 http://hadithtransmitters.hawramani.com/?s=علي+بن+المديني\#cf-85085 (30.09.2021) 


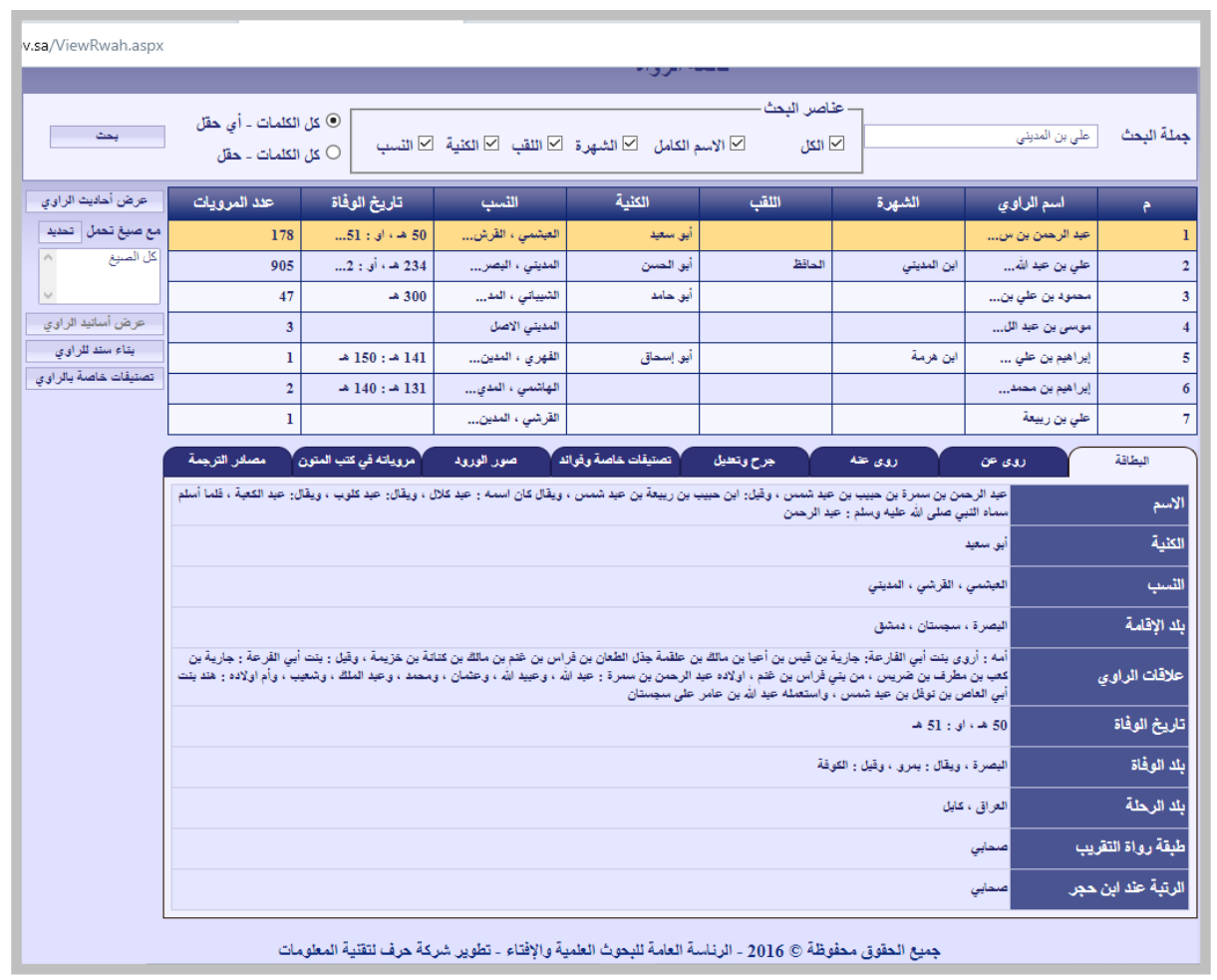

Ekran Görüntüsü 2: Sunnah.alifta.com sitesine ait ekran görüntüsü

Ekran görüntüsü incelendiğinde şu hususiyetlerin ön plana çıktığl görülmektedir: Site üzerindeki arama çubuğu araştırmacılara râvîlerin ismi, lakabı, künyesi, nesebi gibi geniş bir arama kriteri sunmaktadır. Araştırma sonucu benzer isimlerin tefrik edilmesi için bulunan verilerin; lakap, nisbe gibi ayırıcı vasıfları hemen arama çubuğunun altında verilerek pratik bir durum oluşturulmuştur. Aynı şekilde incelenmek istenen kimsenin sütununa dokunulduğunda bir alt grafikte râvînin kimliği, tabaka bilgisi, hakkında dile getirilen cerh-ta'dîl hükümleri, senedinde yer aldığı rivayetler ve aktarlan bu verilerin alındığı kaynaklar gibi faydalı bilgilerin tasnif edilerek sunulduğu görülmektedir. $\mathrm{Bu}$ durum sitenin hazırlanmasında ciddi bir emeğin ortaya konulduğunu göstermektedir. Site, ricâle dair tenkitleri ayrı bir sekmede ve kaynaklarını da vermek suretiyle araştırmacılara büyük kolaylıklar sağlamaktadır. Aynı șekilde herhangi bir münekkidin görüşünü aktarırken farklı kaynakların da dikkate alınması temayüz ettiği vasıflardan birisidir. Cerhta'dîl sekmesine dair ekran görüntüsü şu şekildedir:

12 Sitede alt başlıklar dâhil hadis kitapları, hadis ıstılahları, cerh-ta'dîl lafızları, sözlükler gibi birçok konuya yer verilmiştir. 


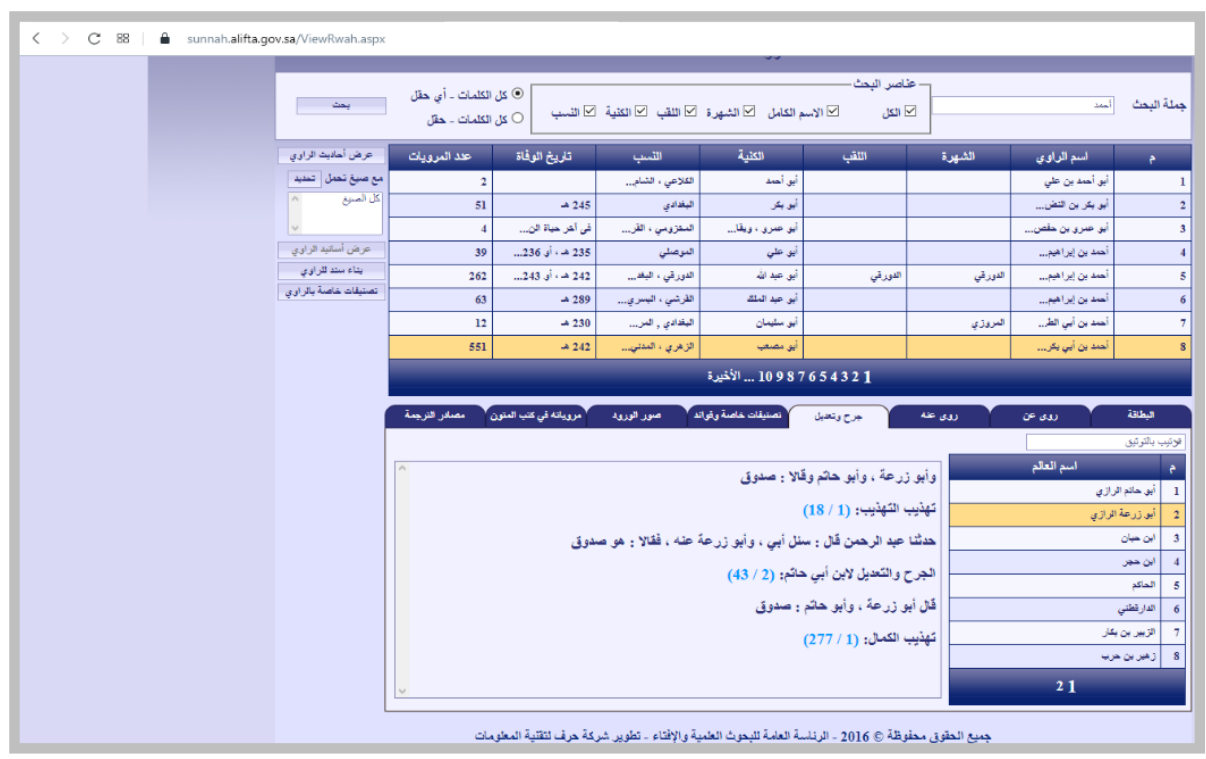

Ekran Görüntüsü 3: Sunnah.alifta.com sitesine ait ekran görüntüsü

$\mathrm{Bu}$ örnek yakından incelendiğinde Ahmed b. Ebûbekir ez-Zührî (ö. 242/856) isimli râvînin Ebu Zür'a (ö. 281/894) tarafından sadûk ifadesiyle değerlendirildiği görülecektir. Site onun bu kanaatini aktarmak üzere Tehzibu'ttehzib, el-Cerh ve't-ta'dîl ve Tehzibu'l-kemâl isimli eserleri kullanmıștır. Bununla birlikte münekkitlere dair kanaatlere ulaşılması için her isme tıklanma gerekliliği bu aşamada sitenin fonksiyonelliğini kısmen zayıflatmaktadır.

\subsection{Hadith Islam}

1400 civarında kitabı ihtiva eden Mevsûâtu'l-hadîs sitesi “Kitaplar, Râvîler, Müellifler ve Kitaplarım" ana bölümlerine sahiptir. ${ }^{13}$ Râvilerle ilgili kısım olan "Ruvât" sekmesine geldiğimizde kullanıcıyı bir araştırma çubuğu karşılamaktadır. Siteye ait ekran görüntüsü şu şekildedir: 


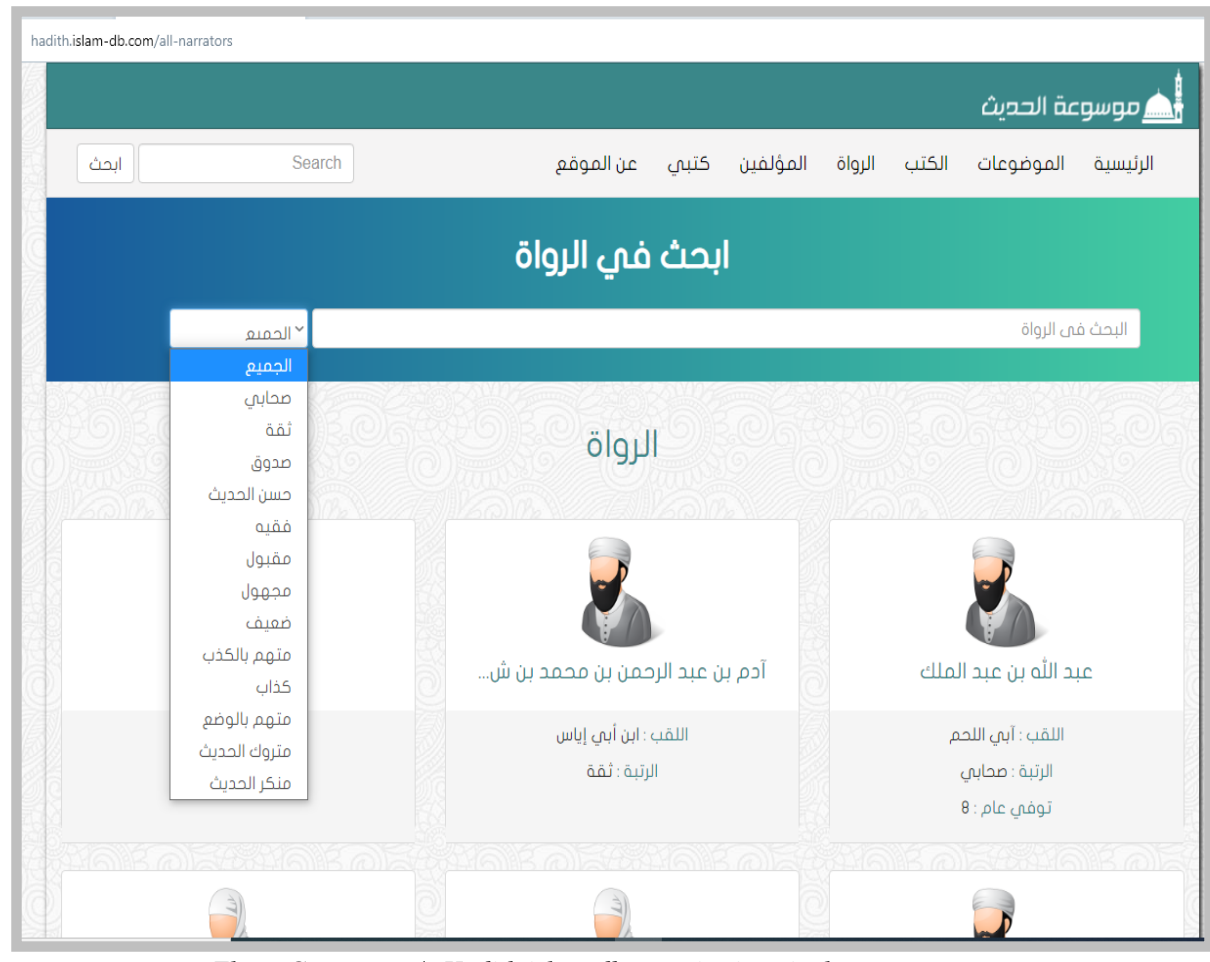

Ekran Görüntüsü 4: Hadith.islam-db.com sitesine ait ekran görüntüsü

Arama çubuğu râvîlerin araştırılmasında "el-Cemîu" seçeneğine ilaveten çeşitli cerh-ta'dîl lafızları ile de arama yapma imkânı sunması açısından diğer sitelerden farklılık arz etmektedir. Arama çubuğuna incelenmek istenen râvî adı yazıldığında râvî adında yer alan lafızları ihtiva eden kelime öbekleri sonuç olarak verilmektedir. Bu kısımda listelenen sonuçların hangisinin gerçekte ulaşmaya çalıştığımız isim olduğunu belirlemek için yer yer manuel kontrol gerekmektedir. Bu duruma, araştırmacıyı eksik bir araştırma yapmaya sevk edebileceğinden dolayı dikkat etmek gerekir. Ricâl sahasında araştırma yapacak kimselerin sıklıkla kullanacağı bu sitede özellikle râvîlerle ilgili sekmeye daha yakından bakmak faydalı olacaktır. Öncelikle sitenin bu kısmına dair ekran görüntüsünü paylaşalım. ${ }^{14}$

14 https://hadith.islam-db.com/narrators/5792/30.09.2021) علي-بن-عبد-اله-بن-جعفر-بن-نجيح) 


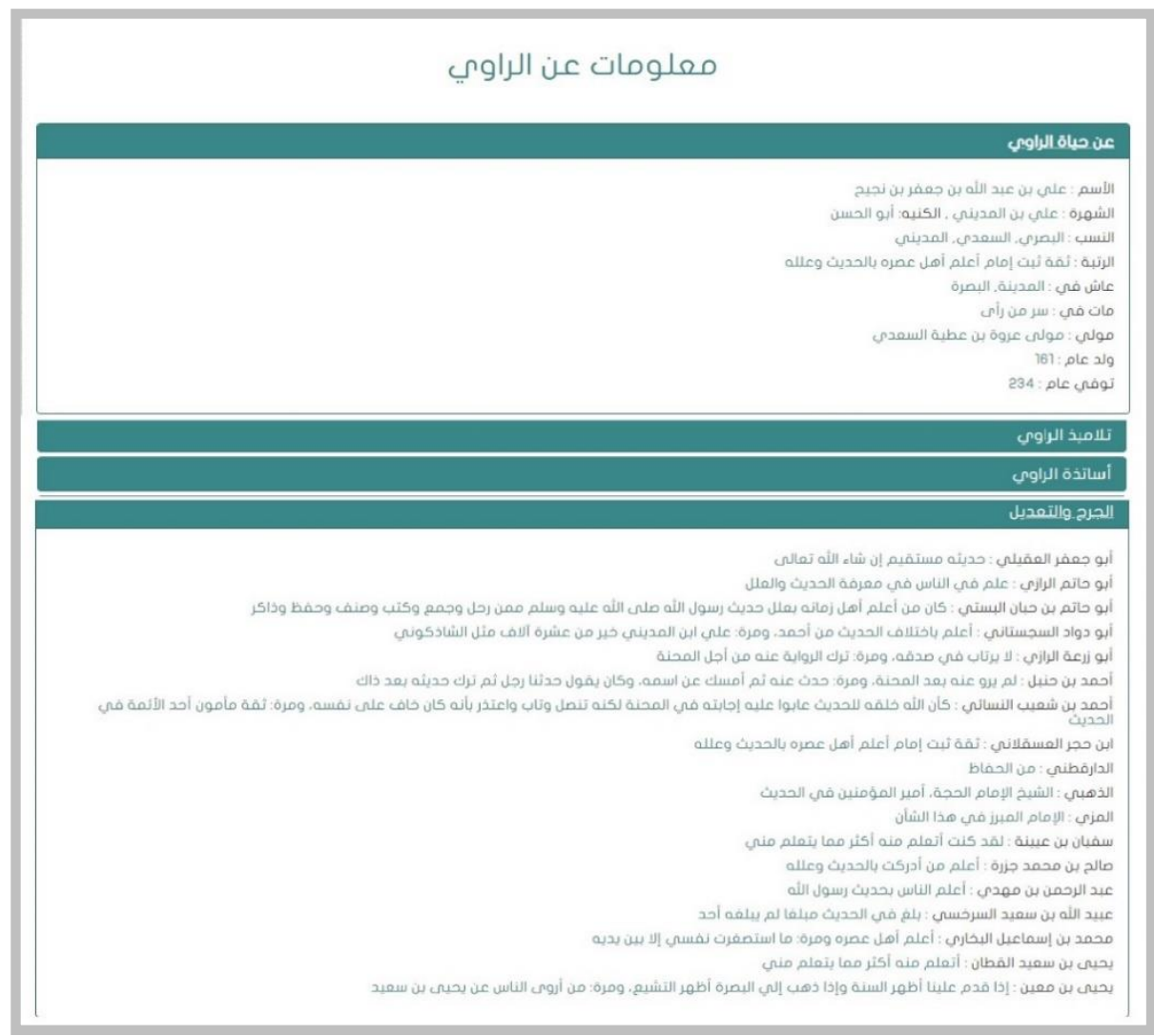

Ekran Görüntüsü 5: Hadith.islam-db.com sitesine ait ekran görüntüsü

$\mathrm{Bu}$ sekme üzerinden herhangi bir râvînin araştırılması dört alt başlık üzerinden sonuç vermektedir. Bunlar ilk olarak; râvînin hayatı kısmıdır. Burada râvînin isim, nisbe, lakap, memleket, doğum ve vefat tarihleri gibi bilgiler sunmaktadır. İkinci ve üçüncü alt bașlıklarda ilgili kișinin tabakasına ișaret eden şeyh ve talebe bilgileri sunulmaktadır. Son kısımda ise râvî hakkında münekkitlere dair cerh-ta'dîl değerlendirmeleri bulunmaktadır. Ruvât sekmesinin muntazam bir şekilde tasnif edilmesi araştırmacılar için önemli bir avantaj sağlamaktadır. Buna ilaveten burada zikredilen isimlerin genellikle vefat tarihleri ile anılmaları da diğer siteler karşısında kendisini ön plana çlkartan bir husustur. Burada özellikle işaret edilmesi gereken kısım ise münekkitlerin değerlendirmelerini kapsayan başlıktır. $\mathrm{Bu}$ kısım, râviler hakkında olabildiğince fazla tenkit ihtiva etmesi ve bunları tek bir tablo altında sunması açısından incelemeye konu olan siteler arasında en fazla fayda sağlayan site olarak ön plana çıkmaktadır. Bununla birlikte sitenin özellikle ricâl hakkındaki değerlendirmeleri kaynaklandırma noktasında bir gayret taşımaması, söz konusu siteyi temel kaynak olmaktan ziyade ara kaynak şeklinde kullanma zorunluluğunu doğurmaktadır. 


\subsection{Islamic Content}

Abdullah Abdülaziz al-Râcîhî vakfı tarafindan desteklenen Islamic Content adlı site, internet üzerinde İslâmî içeriği toplamayı hedeflediğini ifade etmektedir. Suudi Arabistan kaynaklı bu vakfın tarım, sanayi, gayrı menkul sahalarında faaliyette bulunan Abdullah Abdulaziz AlRajhi \& Sons Holding Co isimli bir şirket tarafından yönetildiği/finanse edildiği anlaşılmaktadır. ${ }^{15}$ Söz konusu sitenin ana sayfasında el-A'lâm isimli butona tıklandığında Edebiyat, Tıp, Siyaset, Müfessirler, Muhaddisler gibi çeşitli sahalarda şöhret sahibi kimselerin gruplandırıldığı ikinci bir sayfa çıkmaktadır. Bu gruplardan biri de 71200 veri girişinin olduğu belirtilen "Mu'cemu ruvâtu'l-hadîs" isimli buton altında yer alan râvîlerdir. Bu buton kullanıcılara hem bir arama çubuğu hem de rakamlarla açılan sayfalarda az sayıda râvîden oluşmuş râvî linkleri vermektedir. Sayfanın bu haline ait ekran görüntüsü aşağıdaki şekildedir:

مينة بنت عبد الله

أبان بن أبي عياش العبدي

أبان بن فيروز

أبان بن خالد الحنني.

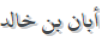

بان بن تغلب

أدم بن علي

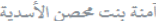

آمثنة بنت محصن بن حرثان بن قيس بن مرة

آمنة

أبان بن تغلب الجريري.

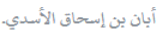

أبان بن إسحاق

Ekran Görüntüsü 6: Islamic Content sitesine ait ekran görüntüsü

Yukarıda ekran görüntüsünü verdiğimiz arayüzde bulunan arama çubuğunu kullanarak gerçekleștirdiğimiz arama " $500 /$ server eror" hatası vermektedir. ${ }^{16}$ Bununla birlikte butonlara tıklandığında ilgili râvî ile alakalı yeni bir sayfa açılmaktadır. Açılan yeni sayfada iki temel başlık altında râvî ile ilgili bilgi verildiği görülmektedir. Bunlardan biri râvînin tanınmasını sağlayacak ad, şöhret, nisbe, yaşadığı bölge ve cerh-ta'dîl açısından durumunu ifade eden kısım diğeri ise hakkında dile getirilen değerlendirmeleri ihtiva eden cerh-ta'dîl başlığıdır. Bu başlığın yetersiz ve geniş butonlara yerleştirilmiş olması araştırmacı için söz konusu sitenin fonksiyonel olmadığı anlamına 
gelmektedir. Bu sitenin en güzel alternatifi hadith-islam.db adlı sitedir. Ebân b. Tağlib (öl.141/758) ile alakalı sayfanın ekran görüntüsü aşağıdaki gibidir. ${ }^{17}$

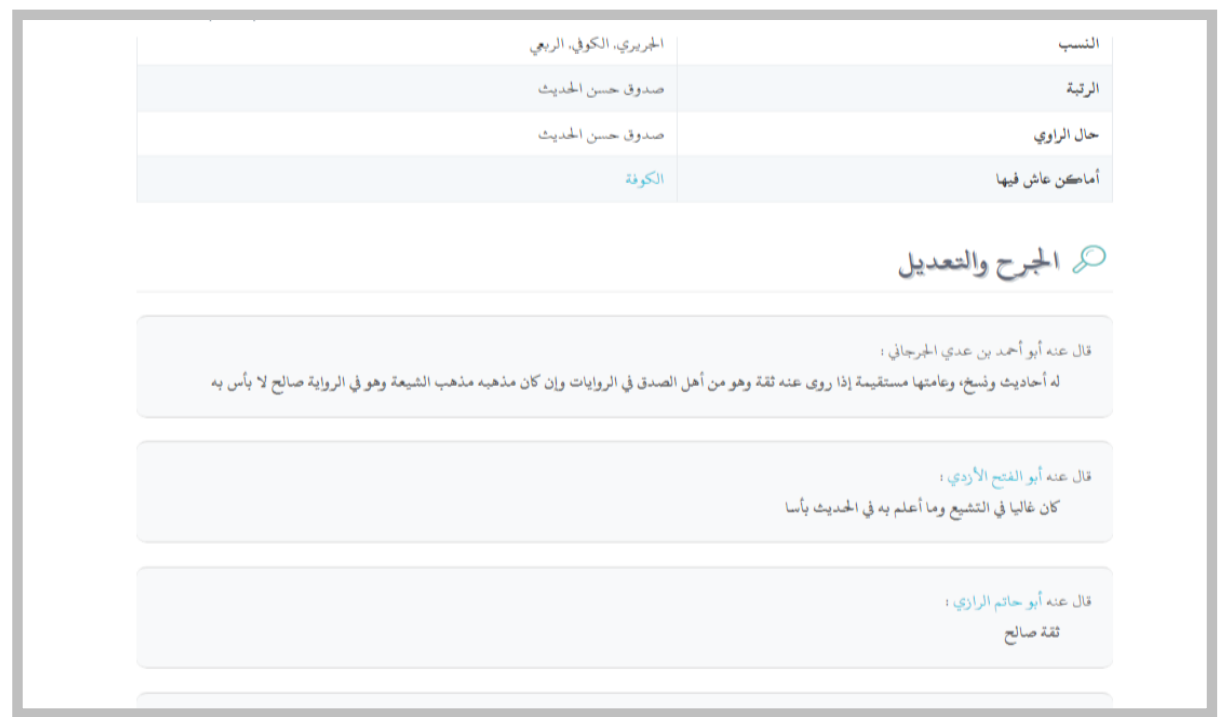

Ekran Görüntüsü 7: Islamic Content sitesine ait ekran görüntüsü

\section{Kapsayıcılık Açısından Sitelerin Mukayesesi}

Yukarıda tanıtımı yapılan sitelerin araştırmacıya kolaylık sağlaması amacıyla kapsam açısından da değerlendirmesi gerekmektedir. Daha önce de zikredildiği üzere söz konusu sitelerden Hadith Islam ve Sunnah al-Ifta ara yüz ve ricâl tenkit değerlendirmelerini barındırma açısından açık ara öne çlkmaktadır. Bu ifade ile birlikte hadis kitaplarında meşhur olan ve daha az tanınan isimlerden iki ismi söz konusu siteler üzerinden araştırarak bir kapasite mukayesesi yapmak yerinde olacaktır. Bu noktada elde edilen bulguları el-Mektebetü'ş-şâmile programı üzerinden de kontrol ederek hem siteleri birbiri ile hem de sitelerin tamamını daha kapsayıcı olan bu program ile mukayese etmiş olacağız. Bu amaçla öncelikle meşhur bir isim olan Ebân b. Tağlib isimli râvî hakkında münekkitlere ait değerlendirmeleri zikretmek istiyoruz.

Zehebî tarafından "sadakati bizim bid'ati kendisinin"18 șeklinde veciz bir ifade ile nitelenen Ebân b. Tağlib şiî bir râvîdir. Onun hakkında münekkitler de genellikle müspet görüş ifade etmişlerdir. Ebân hakkında yaptığımız kapsamlı taramaya dair ulaşılan münekkit görüşleri aşağıdaki şekilde tabloya dökülmüștür. ${ }^{19}$

18 Ebû Abdillah Șemseddîn Muhammed b. Ahmed b. Osman Zehebî, Mîzânu'l-i'tidâl fi nakdî'r-ricâl, nşr. Ali Muhammed Bicâvî (Beyrut: Dârü'l-Ma'rife, ts.), 1:5.

19 İbn Sa'd, et-Tabakâtü'l-Kübrâ, thk. Muhammed Abdülbekir el-Bekrî (Beyrut: Dârü'l-Kütübi'lİlmiyye, 1990), 6:342; Ebû Abdillâh Ahmed b. Muhammed b. Hanbel eș-Șeybânî el-Mervezî İbn 


\begin{tabular}{|c|c|c|c|c|c|}
\hline & $\begin{array}{c}\text { Hadith } \\
\text { Transmitter }\end{array}$ & $\begin{array}{l}\text { Sunnah } \\
\text { al-Ifta }\end{array}$ & $\begin{array}{l}\text { Hadith } \\
\text { Islam }\end{array}$ & $\begin{array}{l}\text { Islamic } \\
\text { Content }\end{array}$ & Shamela \\
\hline $\begin{array}{l}\text { Abdurrahman b. } \\
\text { El-Hakem } \\
\text { er-Razî }\end{array}$ & صعة حديث وأدب & وأدب وعقل حديث & 0 & 0 & \\
\hline Vâkıdî & 0 & 0 & ثقة & 0 & 0 \\
\hline İbn Sad & كان ثقة & كان ثقة & & ثقة & كان ثقة \\
\hline İbn Maîn & ثقة & ثقة & ثقة & ثقة & ثقة \\
\hline İbn Hanbel & ثبت الحديث & ثقة & شيحة ثبث & 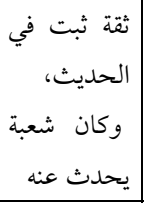 & ثِقَة \\
\hline Cüzcânî & زائغ مذموم المذهب & زائغ مذموم & زائغ & | زائغ مذموم & زائغ $\quad$ المذهب مجاهر مذوم \\
\hline Ebu Hâtim & ثقة & ثقة صالح & ثقة صالح & ثقة صالح & ثقة \\
\hline Yezid b. Harun & 0 & للأخذ عنه يكن أهلا & 0 & 0 & 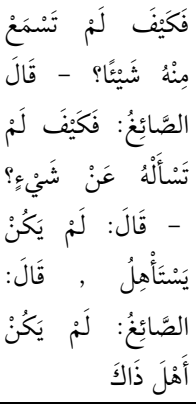 \\
\hline
\end{tabular}

Hanbel, Kitabu'l-ilel ve ma'rifetü'r-ricâl, nşr. Vasiyyullah b. Muhammed Abbas (Riyad: Dâru'lHânî, 1422/2001), 3:284; Ebû İshâk İbrâhim b. Ya'kûb b. İshâk es-Sa'dî Cûzcânî, Ahvâlü'r-ricâl, nşr. Subhî el-Bedri es-Sâmerrâî (Müssesetü'r-Risâle, ts.), 67; Ebû Muhammed Abdurrahmân b. Muhammed b. İdrîs er-Râzî İbn Ebî Hâtim, el-Cerh ve't-ta'dîl, thk. Abdurrahman b. Yahyâ elMuallimî el-Yemânî (Haydarabad, 1953), 2:297; Ebû Ca'fer Muhammed b. Amr b. Mûsâ elUkaylî, Kitâbu'd-duâfâi'l-kebîr, thk. Abdülmu'tî Emîn Kal'acî (Beyrut: Dârü'l-Kütübi'l-İlmiyye, 1984), 1:36; Ebû Hâtim et-Temîmî el-Büstî Muhammed b. Hibbân b. Ahmed İbn Hibbân, Kitâbu's-sikât, nșr. Muhammed b. Abdülmuîn Hân (Dâiratü'l-Maârifi'l-Osmaniyye, 1319/1973), 6:67; Ebû Ahmed Abdullah b. Adî el-Cürcânî İbn Adî, el-Kâmil fi dufâi'r-ricâl, nşr. Adil Ahmed Abdülmevcûd \& Ali Muhammed el-Muavvid \& Abdülfettah Ebû Sünne (Beyrut: Dâru'l-Kütübü'lİlmiyye, ts.), 2:70; Ebu'l Hasan Ali b. Ömer b. Ahmed Dârekutnî, Mevsûâti akvâli Ebi'l-Hasen edDârekutnî fi ricâli'l-hadîs ve ilelihi, nșr. Mahmûd Mehdî es-Silemî \& Eșref Mansûr Abdurrahman \& vd. (Âlemü'l-Kütüb, ts.), 1:27; Ebû Hafs Ömer b. Ahmed b. Osman el-Bağdâdî İbn Şâhîn, Târîhu esmâi's-sikât, nșr. Subhî es-Samerrâî (es-Safâ: Dâru's-Selefiyye, 1984/1404), 38-39; Ebû Abdullah Alâuddin Moğultay b. Kllıç, İkmâlü tehzîbi'l-kemâl fi esmâi'r-ricâl, nşr. Âdil b. Muhammed \& Üsâme b. İbrahim (Kahire: el-Fârûk el-Hadîsiyye li't-Tibâati ve'n-Neşr, 1422/2001), 1:157-59; Ebû Abdillah Șemseddîn Muhammed b. Ahmed b. Osman Zehebî, Men tüküllime fihi ve hüve müvessak, nșr. Abdullah b. Dayfullah er-Rahîlî (Medine, 1406/1986), 5758; Ebü'l-Fazl Şihâbüddîn Ahmed b. Alî b. Muhammed el-Askalânî İbn Hacer, Takrîbu't-tehzîb, nşr. Muhammed Avvâme (Haleb: Dâru'r-Reşî, 1411/1991), 87. 


\begin{tabular}{|c|c|c|c|c|c|}
\hline İbn Halfun & 0 & | توهو ثقمة في مذهبه ، & 0 & 0 & 0 \\
\hline $\begin{array}{l}\text { Muhammed } \quad \text { b. } \\
\text { Aclân } \\
\text { el-Medenî }\end{array}$ & 0 & |ثقة & ثقة & ثقة | لقة & 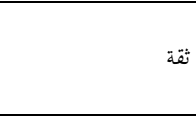 \\
\hline Nesâî & 0 & |ثقة & ثقة & ثقة & ثقة \\
\hline Ukaylî & 0 & 0 & 0 & 0 & فاتمهد \\
\hline İbn Ebi Hâtim & 0 & 0 & 0 & 0 & \\
\hline İbn Hibban & في الثقات & | في الثقات & 0 & 0 & في الثقات \\
\hline İbn Adî & من أهل الصدق & | من أهل الصدق & من أهل الصدق & من & من أهل الصدق \\
\hline Ezdî & 0 & 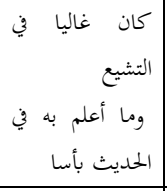 & 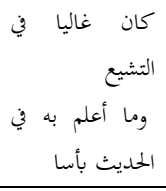 & 0 & 0 \\
\hline Darekutnî & 0 & 0 & 0 & 0 & غيره أحفظ منه \\
\hline İbn Şahin & 0 & في " جملة الثقات & 0 & 0 & في " جملة الثقات \\
\hline Hâkim & 0 & | ثقة & ثقة & | مقة & ثقة \\
\hline Ebu Nuaym & 0 & 0 & 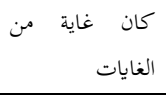 & 0 & 0 \\
\hline İbn Cevzî & في الضعفاء & 0 & 0 & 0 & 0 \\
\hline Zehebî & الإِمَامُ، المُمْرِئُ، أَبَوُ سَعْدٍ & | ثقة شيعي & 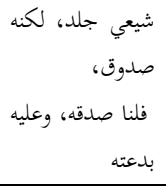 & فلنا & صدوق مشهور \\
\hline İbn Hacer & 0 & |لتشيع ت تكلم فيه & 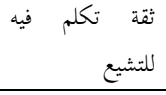 & ثلتشة تكلم فيه & ثقة تكلم فيه للتشيع \\
\hline Aynî & 0 & 0 & 0 & 0 & ثقة، تكلم فيه للتشيع \\
\hline Mansur & 0 & 0 & 0 & 0 & كَذَبْتَتَ كَذَبْنَ، وَصَاحَ \\
\hline Toplam & 10 & 17 & 13 & 11 & 18 \\
\hline
\end{tabular}

Tabloda yer alan sütunlar tarama yapılan kaynaklara işaret etmektedir. Öncelikle el-Mektebetü'ş-şâmile programı ile Sunnah al-Ifta adlı siteden elde edilen bulguların birbirine yakınlığı göze çarpmaktadır. $\mathrm{Bu}$ durum internet tabanlı kaynaklar arasında söz konusu sitenin önemli bir bașvuru kaynağ olacağına da işaret etmektedir. Bununla birlikte Sunnah al-Ifta sitesi için araștırma esnasında karşılașılan iki probleme işaret etmekte yarar bulunmaktadır. Bunlardan ilki, basılı kaynak mantığından hareketle bir 
münekkide ait görüşün defaatle tekrar edilmesidir. Dile getirilmesi gereken ikinci bir husus ise münekkitlere dair görüşlerin tek bir tablo yerine ayrı birer sayfa halinde verilmesidir. Bu durumun temel problemi, araștırmacının her bir münekkidin görüşüne ulaşmak için yeni bir sekmenin açılmasını sağlama külfetine mecbur bırakılmasıdır.

İslamic Content ve Hadith Transmitter sitelerinin daha az münekkit görüşüne yer verdiği görülmektedir. Bu durum aslında söz konusu sitelerin kapsayıcılık iddiasının bulunmadığı ya da bu iddianın tatbik edilmediğini göstermektedir. Yukarıdaki beș dijital kaynakta yer alan ortak münekkitlere bakıldığında İbn Maîn (ö. 233/848), İbn Hanbel (ö. 241/855), Cüzcânî (ö. 259/873), Ebu Hatim (ö. 277/890), İbn Adî (ö. 365/976), Zehebî (ö. 748/1348) ve İbn Hacer (ö. 852/1449)'in vaz geçilmez isimler olduğu söylenebilir. Çünkü zikredilen bütün isimler Ebân b. Tağlib özelinde kendilerine yer bulabilmișlerdir.

Tablodaki Ebu Nuaym ismine nispet edilen كان غاية من الغايات ifadesi bazl sitelerde Ebu Nuaym el-İsfehânî (ö. 430/1038) bazı sitelerde ise Ebu Nuaym elFadl b. Dükeyn (ö. 219/834) şeklinde zikredilmiștir. ${ }^{20}$ Bu karışıklığın pratik sonucu ise tek bir site ile yetinecek araștırmacının yanlıș yönlendirilmesidir. Bu sebeple kitapların baskısı ile uyumu dikkate alınarak araştırmalarda elMektebetü'ş-şâmile programının kullanılması bununla da yetinmeyerek kullanılması istenen kaynağın baskısına müracaat edilmesi gerekmektedir.

$\mathrm{Bu}$ başlık altında inceleyeceğimiz ikinci kişi Cümey' b. Ömer b. 102 Abdurrahman el-Kûfî (ö. 181-190)'dir. Bu râvî hakkında kanaat belirten münekkitlere ait bulguların tablosu şu şekildedir: ${ }^{21}$

\begin{tabular}{|c|c|c|c|c|c|}
\hline & Hadith Transmitter & $\begin{array}{l}\text { Sunnah } \\
\text { al-Ifta }\end{array}$ & Hadith Islam & \begin{tabular}{|l|} 
Islamic \\
Content \\
\end{tabular} & Shamela \\
\hline İclî & 0 & حديثه وليس بالقوي به يكتب & حلا لأس به به يكتب بالقوي & 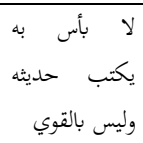 & 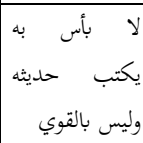 \\
\hline Ebu Davud & 0 & كذابا & كذابا & أخشى $\begin{array}{r}\text { أن كذابا } \\
\end{array}$ & كذابا \\
\hline Ebu'l-Arab & 0 & في "جملة الضعفاء" & 0 & 0 & الضعفاء" \\
\hline Nesâî & 0 & 0 & ثقة & ثقة & 0 \\
\hline İbn Hibban & ل & ي & 0 & 0 & في الثقات \\
\hline
\end{tabular}

20 el-Fadl b. Dükeyn'e ait tarih kitabının bulunmadığına dair bakınız: Mahmut Yazıcı, "Hadis Tarihinin Geçiș Dönemi Âlimlerinden Ebû Nu'aym el-Fadl b. Dükeyn (ö. 219/834) ve Günümüze Ulaşmayan et-Târih Adlı Eseri Üzerine", PAUIFD 7/2 (ts.), 1552; Bu ifadenin el-Fadl b. Dükeyn'e aidiyyeti için bakınız: Moğultay b. Kılıç, Ikmâl, 1:158.

21 İbn Hibbân, Kitâbu's-sikât, 8:166; Moğultay b. Kılıç, Íkmâl, 3:238; İbn Hacer, Takrîbu't-tehzîb, 142. 


\begin{tabular}{|c|c|c|c|c|c|}
\hline İbn Adî & 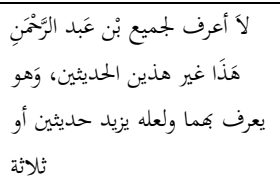 & 0 & 0 & 0 & 0 \\
\hline $\begin{array}{ll}\text { el-Fazl } & \text { b. } \\
\text { Dükeyn } & \\
\end{array}$ & كان فاسقا & كان فاسقا & 0 & 0 & فسقه \\
\hline İbn Hacer & 0 & ضعيف رافضي & ضعيف رافضي & ضعيف رافضي & ضعيف رافضي \\
\hline Toplam & 3 & 6 & 4 & 4 & 8 \\
\hline
\end{tabular}

Tablo 2: Cümey’ b. Ömer b. Abdurrahman el-Kûfî hakkında münekkitlerin değerlendirmeleri

Tabloda yine ilk dikkati çeken husus Dârekutnî (ö. 385/995)'nin ifadesi göz ardı edildiğinde Sunnah al-Ifta ile el-Mektebetü'ş-şâmile programı arasındaki uyumdur. $\mathrm{Bu}$ durum, araştırmacı açısından ricâl tenkit araștırmalarında Sunnah al-Ifta sitesinin iyi bir internet sayfası olduğu şeklinde okunabilir. Tabloda Nesâî (ö. 303/915)'ye nispet edilen görüşlerin hem Sunnah al-Ifta hem de eş-Şâmile sorgusunda listelenmemesi her iki sitenin daha çok uyum halinde olduğunu gösteren ikinci veridir. Bununla birlikte Nesâî’ye nispet edilen görüşün, yaptığımız araştırmalarda bulunamaması da dijital kaynaklar üzerinden çalışırken temkinli olmamız gerektiğini göstermektedir. Kaldı ki tabloda yer verilen ricâl değerlendirmelerinden sadece Nesâînnin Cümey'i tevsik ettiği anlaşılmaktadır. Bu durum meselenin daha da önemli olduğunu gösteren bir başka husustur.

Hadith Transmitter sitesi bir önceki tabloda da \%50'nin altında bir veri sunmuştu. İncelenen iki isimden hareketle adı geçen sitenin ricâl tenkit araștırmalarında yeterli olmadığı ifade edilebilir. Ayrıca bu site İbn Adî̀nin eserinden doğrudan aktarımda bulunurken Sunnah al-Ifta sitesi İbn Adî'nin incelediğimiz râvîyi dedesine nispet ettiğini ifade etmiștir. Bu durum da her iki site arasında "kişi veri tabanlı listelemede" metnin işlenmesi gerektiğini göstermektedir.

Netice olarak kapsayıcılık açısından sitelerin birbiri ve el-Mektebetü’şşâmile programı ile mukayesesi öncelikle Sunnah al-Ifta ve Hadith-islam-db adlı sitelerin sırasıyla en kapsamlı siteler olduğunu göstermektedir. Çevrimiçi kaynak olmaları internet erişiminin olduğu her ortamda mobil cihazlar dahil veri alışverişini mümkün kılarken bu durum sıfır hata garantisi vermemektedir. Bunun birkaç temel sebebinden bahsedilebilir. Bu sebeplerden ilki, insan faktöründen kaynaklanan muhtemel problemler iken ikincisi, ricâl tenkit edebiyatında nadiren de olsa kimlik tespitinin zorluğu ya da tenkitlerin aidiyetinde yapılan hatalardır. Bu duruma yukarıda Ebu Nuaym ile ilgili dile getirilen husus örnek olarak gösterilebilir.

\section{Sonuç}

Ricâl tenkit sahası, araştırma ve incelemeler yapılmak suretiyle hala aktüalitesini korumaktadır. Bu sebeple kaynaklarımızın da gelişen dünyaya ayak uydurması gerekmektedir. Bu durumun başlıca yolu söz konusu kaynakların çevrimiçi dijital dünyaya aktarılmasıdır. Dünya çapında bazı 
kişi/grup ya da devlet desteği ile bir takım internet siteleri oluşturulmuştur. Bu durum, araştırmacılar açısından elbette olumlu bir gelişmedir. Bununla birlikte doğasında terakki olan "gelişme" durmadan devam etmelidir. Bu makalede de söz konusu siteler incelenerek kısa bir değerlendirme yapılmıştır. Öncelikle bu değerlendirmelerin sınırlı site ve râvî sayısı üzerinden gerçekleştirildiği dikkate alınmalıdır.

Hadis râvîlerine dair ülkemizde yeterli bir sitenin olmadı̆̆ edilmelidir. Buna ilaveten incelenen sitelerden özellikle Sunnah al-Ifta ve Hadith-islam.db'nin araştırmacılar için faydalı birer dijital platform olduğu söylenebilir. Sunnah al-ifta adlı site, kapsayıcılık açısından el-Mektebetü'şşâmile programına yaklaşarak diğer üç siteye ihtiyaç bırakmayacak bir hüviyete sahiptir. Bununla birlikte kullanım açısından Hadith-islam.db adlı sitenin ön plana çıktığını söylemeliyiz. Şu durumda özellikle ülkemizde her iki siteyi mezcedecek bir web sayfasının oluşturulması bu sahada araştırma yapacak genç araştırmacılara daha fazla fayda sağlayacaktır. Söz konusu sitenin adı "hadisravileri" gibi doğrudan râvîleri çağrıștırmalı, mümkünse sadece münekkitlere ait teknik terimler zikredilmeli ve gereksiz grafik, sekme ya da pop-up menü/drop dawn list'lerden arınmış olmalıdır. Ayrıca münekkitlere ait bulgular tek bir listede verilmeli, bu liste içerisine açılır pencere linki verilerek kaynakçaya ulaşılabilmelidir. Elbette bu noktada dile getirilen öneriler, tek bir kişinin gerçekleștirebileceği nitelikte değildir. Bunun için bilgisayar teknolojisi ve saha ile ilgili tecrübeye sahip kişilerden oluşan ekip kurularak sürecin 104 planlanması yapılmalıdır.

\author{
Finansman / Funding: \\ This research received no external funding. / Bu araștırma herhangi bir dış fon \\ almamiștır. \\ Çıkar Çatışması / Conflicts of Interest: \\ The author declare no conflict of interest. / Yazar, herhangi bir çıkar çatışması \\ olmadığını beyan eder.
}




\section{Kaynakça}

Cûzcânî, Ebû İshâk İbrâhim b. Ya'kûb b. İshâk es-Sa'dî. Ahvâlü'r-ricâl. nșr. Subhî el-Bedri esSâmerrâî. Müssesetü'r-Risâle, ts.

Dârekutnî, Ebu'l Hasan Ali b. Ömer b. Ahmed. Mevsûâti akvâli Ebi'l-Hasen ed-Dârekutnî fi ricâli'lhadis ve ilelihi. nșr. Mahmûd Mehdî es-Silemî \& Eşref Mansûr Abdurrahman \& vd. 2 Cilt. Âlemü'l-Kütüb, ts.

İbn Adî, Ebû Ahmed Abdullah b. Adî el-Cürcânî. el-Kâmil fi dufâi'r-ricâl. nşr. Adil Ahmed Abdülmevcûd \& Ali Muhammed el-Muavvid. 9 Cilt. Beyrut: Dâru'l-Kütübü'l-İlmiyye, ts.

İbn Ebî Hâtim, Ebû Muhammed Abdurrahmân b. Muhammed b. İdrîs er-Râzî. el-Cerh ve't-ta'dîl. thk. Abdurrahman b. Yahyâ el-Muallimî el-Yemânî. 9 Cilt. Haydarabad, 1. Basım, 1953.

İbn Hacer, Ebü'l-Fazl Şihâbüddîn Ahmed b. Alî b. Muhammed el-Askalânî. Takrîbu't-tehzîb. nșr. Muhammed Avvâme. Haleb: Dâru'r-Reşîd, 3. Basım, 1411/1991.

İbn Hanbel, Ahmed b. Muhammed b. Hanbel eș-Șeybânî el-Mervezî. Kitabu'l-ilel ve ma'rifetü'r-ricâl. nșr. Vasiyyullah b. Muhammed Abbas. 4 Cilt. Riyad: Dâru'l-Hânî, 2. Basım, 1422/2001.

İbn Hibbân, Ebû Hâtim et-Temimî el-Büstî Muhammed b. Hibbân b. Ahmed. Kitâbu's-sikât. nșr. Muhammed b. Abdülmuîn Hân. 10 Cilt. Dâiratü'l-Maârifi'l-Osmaniyye, 1. Basım, 1319/1973.

İbn Sa'd, Ebû Abdillâh Muhammed b. Sa'd b. Menî‘ el-Kâtib el-Hâşimî el-Basrî el-Bağdâdî. etTabakâtü'l-Kübrâ. thk. Muhammed Abdülbekir el-Bekrî. 8 Cilt. Beyrut: Dârü'l-Kütübi'lİlmiyye, 1. Basım, 1990.

İbn Şâhîn, Ebû Hafs Ömer b. Ahmed b. Osman el-Bağdâdî. Târîhu esmâi's-sikât. nşr. Subhî esSamerrâî. es-Safâ: Dâru's-Selefiyye, 1984/1404.

Moğultay b. Kılıç, Ebû Abdullah Alâuddin. İkmâlü tehzîbi'l-kemâl fi esmâi'r-ricâl. nşr. Âdil b. Muhammed \& Üsâme b. İbrahim. 12 Cilt. Kahire: el-Fârûk el-Hadîsiyye li't-Tıbâati ve'n-Neşr, 1. Basım, 1422/2001.

Ukaylî, Ebû Ca'fer Muhammed b. Amr b. Mûsâ el-. Kitâbu'd-duâfâi'l-kebîr. thk. Abdülmu'tî Emîn Kal'acî. 4 Cilt. Beyrut: Dârü'l-Kütübi'l-İlmiyye, 1. Basım, 1984.

Yazıcı, Mahmut. "Hadis Tarihinin Geçiş Dönemi Âlimlerinden Ebû Nu'aym el-Fadl b. Dükeyn (ö. 219/834) ve Günümüze Ulașmayan et-Târih Adlı Eseri Üzerine”. PAUIFFD 7/2 (ts.), 15261556.

Yılmaz, Hayati. "İçerik, Sunum ve Nitelikleri Bakımından Türkçe İnternet Sayfalarında Hadis". Sakarya Üniversitesi İlahiyat Fakültesi Dergisi 16 (2007), 63-76.

Yılmaz, Hayati. “Internette Rıhle”. Hadis Tetkikleri Dergisi 2/1 (2004).

Zehebî, Ebû Abdillah Şemseddîn Muhammed b. Ahmed b. Osman. Men tüküllime fíhi ve hüve müvessak. nșr. Abdullah b. Dayfullah er-Rahîlî. Medine, 1. Basım, 1406/1986.

Zehebî, Ebû Abdillah Şemseddîn Muhammed b. Ahmed b. Osman. Mîzânu'l-i'tidâl fi nakdî'r-ricâl. nşr. Ali Muhammed Bicâvî. Beyrut: Dârü'l-Ma'rife, ts.

https://www.google.com/search?client=opera\&q=رجال+الحديثsourceid=opera\&ie=UTF-8\&oe=UTF-8 (28.09.2021)

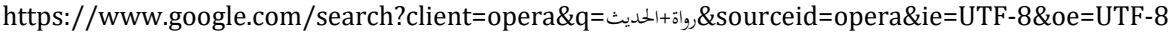
(28.09.2021)

https://www.google.com/search?client=opera\&q=eالجرح+والتعديل\&sourceid=opera\&ie=UTF-8\&oe=UTF-8 (28.09.2021)

https://www.google.com/search?q=hadith+transmitter\&client=opera\&hs=ime\&ei=TBJSYf330-X 7_UPgfy0qAs\&start=0\&sa=N\&ved=2ahUKEwj9zfz96J_zAhVl_7sIHQE-

DbU4FBDy0wN6BAgBEDw\&biw=1222\&bih=587\&dpr=1.31 (28.09.2021)

(http://hadithtransmitters.hawramani.com/hatim-b-arif-al-awni-dhayl-lisan-al-mizan/ (30.09.2021)

http://hadithtransmitters.hawramani.com/?s=علي+بن+المديني+fcf-85085 (30.09.2021)

https://hadith.islam-db.com

https://hadith.islam-db.com/narrators/5792/30.09.2021 30.09.2021) علي-بن-عبد-الله-بن-جعفر-بن-نجيح (30.0921)

https://www.linkedin.com/company/abdullah-abdulaziz-al-rajhi-holding-co (30.09.2021)

https://islamic-content.com/search?query=أبان+بن+تغلب-\&type=narrator (30.09.2021)

https://islamic-content.com/person/9 (30.09.2021 